\title{
Penggunaan Agens Hayati Pseudomonas fluorescens terhadap Pertumbuhan Tanaman Kedelai (Glycine max L. Merr,)
}

\author{
Wuryantoro $^{1}$, Wuye Ria Andayanie ${ }^{2}$, Ndaru Hadian Dhuhava ${ }^{3}$ \\ Program Studi Agroteknologi, Universitas Merdeka Madiun, Jl. Serayu No.79, Madiun, 663133 \\ E-mail: wuryantoro@unmer-madiun.ac.id \\ Program Studi Agroteknologi, Universitas Merdeka Madiun, Jl. Serayu No.79, Madiun, 663133 \\ E-mail: wuye.andayanie@gmail.com \\ Program Studi Agroteknologi, Universitas Merdeka Madiun, Jl. Serayu No.79, Madiun, 663133 \\ E-mail: -
}

\begin{abstract}
Soybean (Glycine max L.) is the third most important food commodity after rice and corn in Indonesia. This study aims to determine the interaction of soybean growth that has been incubated using Pseudomonas fluorescens. The research method used a randomized block design experiment consisting of five treatments, namely S1 (soybean seeds were given Pseudomonas fluorescens and not incubated), S2 (soybean seeds were given Pseudomonas flourescen and incubated for 6 hours), S3 (soybean seeds were given Pseudomonas flourescens and incubated for 12 hours), S4 (soybean seeds were given Pseudomonas flourescens and incubated for 18 hours), and S5 as a control. The test used univariate analysis and further tested with Duncan's test with a level of 5\%. The results showed that there was no significant effect on the use of Pseudomonas flourescens as a soybean seed incubation material on the parameters of plant height, leaf area, wet weight, and dry weight of soybean plants.
\end{abstract}

Keywords—: Soybean; Pseudomonas fluorescens; incubation; seeds; biological agents.

\section{PENDAHULUAN}

Kedelai (Glycine max L.) termasuk komoditas pangan ketiga terpenting setelah padi dan jagung di Indonesia. Budidaya kedelai dapat mengalami gangguan penyakit sejak awal tanaman oleh Organisme Pengganggu Tanaman (OPT).

Hal ini karena rendahnya mutu benih kedelai yang tidak tahan lama dalam penyimpanan. Perlakukan benih sering menggunakan fungisida sintetis untuk mengendalikan penyakit yang disebabkan oleh Rhizoctonia sp. Namun, penggunaan fungisida sintetis mulai dibatasi pengunaannya karena dapat berdampak negatif terhadap manusia maupun bagi lingkungan.

Pengendalian hayati digunakan untuk meningkatkan pertumbuhan tanaman khususnya produksi kedelai yang ramah lingkungan. Oleh karena itu pengendalian hayati saat ini semakin mendapat perhatian petani. Saat ini bakteri Pseudomonas fluorescens banyak dimanfaatkan sebagai agens hayati. Rizobakteri dari genus Pseudomonas, Bacillus dapat meningkatkan pertumbuhan tanaman, menguraikan dinding sel patogen dan menghambat pertumbuhan patogen dengan menghasilkan senyawa antimikroba seperti siderofor (Diniyah, 2010). Selain itu, penambahan Rhizobium dan Pseudomonas fluorescens mampu meningkatkan pertumbuhan tanaman kedelai pada tanah salin ( Zulaikah dan Yuliani, 2018). Bakteri Pseudomonas fluorescens menghasilkan pigmen berwarna hijau kuning yang dapat digunakan untuk identifikasi serta klasifikasi dari senyawa fluorescence atau pyoverdin yang berpendar di bawah cahaya ultraviolet (panjang gelombang $266 \mathrm{~nm}$ (Nawangsih et.al., 2014). Peningkatan pertumbuhan tanaman dan pengendalian penyakit dengan menggunakan $P$. fluorescens merupakan salah satu alternatif pengelolaan tanaman kedelai yang ramah lingkungan, berkesinambungan dan dapat diintegrasikan dalam program pengendalian hama terpadu (Yanti et al., 2013). Pseudomonas fluorescens dapat mengurangi persentase serangan $R$. solanacearum karena mampu memproduksi metabolik sekunder seperti siderofor, poluteorin, pirrolnitrin, filoroglusinol serta fenazin dan semua antibiotik tersebut termasuk golongan fenol yang menghambat pertumbuhan bakteri $R$. solanacearum (Rosyidah et al., 2013).

Kemampuan Rizobakteria meyuburkan tanaman dan mengendalikan penyakit pada berbagai komoditas telah banyak dilaporkan, tetapi penggunaan rizobakteria dari lingkungan habitat tanaman kedelai belum pernah dilaporkan. Berdasarkan uraian diatas maka perlu dilakukan penelitian perlakuan benih menggunakan Pseudomonas fluorescens yang merupakan rizobakteri pemacu pertumbuhan tanaman (RPTT). Penelitian ini bertujuan menguji perlakuan pemberian Pseudomonas flourescen terhadap pertumbuhan tanaman kedelai dan pengaruh perlakuan lama inkubasi Pseudomonas flourescen terhadap pertumbuhan tanaman kedelai. 
Website : http://agritek.unmermadiun.ac.id/index.php/agritek

\section{METODE PENELITIAN}

\section{A. Tempat dan Waktu Penelitian}

Penelitian dilaksanakan pada bulan Mei sampai Agustus 2021 di lahan Fakultas Pertanian Universitas Merdeka Madiun dan juga di Wilker UPT Proteksi Tanaman dan Holtikultura di Pilangkenceng Kabupaten Madiun. Benih kedelai varietas Anjasmoro diperoleh dari Balai Penelitian Aneka Kacang dan Umbi (Balitkabi) Malang.

\section{B. Metode Penelitian}

1. Penghitungan kerapatan koloni bakteri

Penghitungan kerapatan koloni bakteri dilakukan dengan cara melarutkan isolate Pseudomonas flourescens dengan air suling sebanyak $200 \mathrm{ml}$, lalu buat pengenceran $10^{-6}$ dengan cara mengambil $1 \mathrm{ml}$ akuadest. Selanjutnya dimasukkan ke dalam gelas ukur tambah $9 \mathrm{ml}$ air suling kocok merata, kemudian dari pengenceran pertama diambil $1 \mathrm{ml}$ dan ditambahkan $9 \mathrm{ml}$ air suling kocok merata. Langkah ini dilakukan hingga pengenceran ke 6 kali. Larutan ini diambil 1 mili dan kemudian diteteskan ke media PDA dalam petridish, goyang/putar kurang lebih 30 kali agar menyebar merata kemudian di inkubasi selama 24 jam didalam ruang laminar air flow. Setelah 24 jam bakteri dapat diamati dan dihitung jumlah koloni pada media tersebut.

Pada pengujian ini diuji 3 sampel isolat dan diambil jumlah kerapatan koloni tertinggi. Sampel ke 2 memiliki kerapatan koloni tertinggi yaitu 7 × $10^{-6}$ dan dipilih untuk perlakuan benih kedelai.

2. Analisis data

Metode penelitian menggunakan Rancangan Acak Kelompok (RAK). Penelitian ini terdiri atas lima perlakuan (empat perlakuan dengan Pseudomonas fluorescens dan satu perlakuan tanpa Pseudomonas fluorescens). Tiap perlakuan diuji pada 6 tanaman dengan tiga kali ulangan. Perlakuan tersebut terdiri atas:

Perlakuan (S1) : Perlakuan benih dengan Pseudomonas fluorescens dan tidak di inkubasi

Perlakuan (S2): Perlakuan benih dengan Pseudomonas flourescens dan di inkubasi selama 6 jam

Perlakuan (S3): Perlakuan benih dengan Pseudomonas flourescens dan di inkubasi selama 12 jam

Perlakuan (S4): Perlakuan benih dengan Pseudomonas flourescens dan di inkubasi selama 18 jam

Perlakuan (S5): Perlakuan benih tanpa Pseudomonas flourescens

Data dianalisis menggunakan analisis ragam (ANOVA) dan program Microsoft Office Excel 2007 serta SPSS versi 17.0 (Statistical Package for Social Sciences, USA). Pengaruh perlakuan yang berbeda nyata dilakukan uji lanjut dengan uji selang berganda Duncan (DMRT) pada taraf nyata $5 \%$.

\section{III.HASIL DAN PEMBAHASAN}

\section{A. Hasil}

Hasil analisis statistik menunjukan bahwa lama inkubasi terhadap pertumbuhan tinggi tanaman kedelai tidak berpengaruh nyata. Perlakuan inkubasi tanaman kedelai pada 14 Hari setelah tanam (HST) didapatkan tinggi tanaman tertinggi pada perlakuan S5 (tanpa perlakuan Pseudomonas flourescens dan tanpa inkubasi ) yaitu 12,17 gram, dan tinggi tanaman terendah perlakuan S1 (pemberian Pseudomonas flourescens dan tanpa inkubasi) yaitu 11,31 gram, sedangkan pada 7 HST didapatkan hasil tertinggi pada perlakuan S5 (tanpa perlakuan Pseudomonas flourescens dan tanpa inkubasi ) yaitu 17,73 gram dan tinggi tanaman terendah perlakuan S1 (pemberian Pseudomonas flourescens dan tanpa inkubasi) yaitu 16,44 gram, sedangkan pada 7 didapatkan hasil tertinggi pada perlakuan S5 (tanpa perlakuan Pseudomonas flourescens dan tanpa inkubasi) yaitu 24,81 gram, dan tinggi tanaman terendah pada perlakuan S1 (pemberian Pseudomonas flourescens dan tanpa inkubasi) yaitu 23,38 gram. Nilai rata-rata interaksi antara faktor inkubasi terhadap pertumbuhan tinggi tanaman tersaji dalam Tabel 1.

Tabel 1.

Nilai rata rata tinggi tanaman $(\mathrm{cm})$ pada faktor lama inkubasi biji kedelai terhadap pertumbuhan tinggi tanaman kedelai

\begin{tabular}{cccc}
\hline Lama inkubasi & 14 HST & 21 HST & 28 HST \\
\hline S1 & $11,31 \mathrm{a}$ & $16,44 \mathrm{a}$ & $23,38 \mathrm{a}$ \\
S2 & $11,87 \mathrm{a}$ & $17,45 \mathrm{ab}$ & $24,63 \mathrm{a}$ \\
S3 & $11,75 \mathrm{a}$ & $17,60 \mathrm{ab}$ & $24,75 \mathrm{a}$ \\
S4 & $11,95 \mathrm{a}$ & $17,47 \mathrm{ab}$ & $24,46 \mathrm{a}$ \\
S5 & $12,17 \mathrm{a}$ & $17,73 \mathrm{~b}$ & $24,81 \mathrm{a}$
\end{tabular}

Keterangan : Angka-angka yang diikuti oleh huruf yang sama tidak berbeda nyata pada uji Duncan taraf $5 \%$.

Hasil analisis statistik menunjukan bahwa lama inkubasi terhadap pertumbuhan luas daun tanaman kedelai tidak berpengaruh nyata. Perlakuan inkubasi tanaman kedelai dari hasil nilai rata-rata interaksi perlakuan waktu inkubasi biji terhadap 
Website : http://agritek.unmermadiun.ac.id/index.php/agritek

pertumbuhan luas daun tanaman kedelai pada 14 HST didapatkan luas daun tanaman tertinggi pada perlakuan S2 (pemberian Pseudomonas flourescens dan inkubasi 18 jam ) yaitu $20,58 \mathrm{~cm}^{2}$, dan luas tanaman terendah adalah $\mathrm{S} 1$ (pemberian Pseudomonas flourescens dan tanpa inkubasi) yaitu $19,50 \mathrm{~cm}^{2}$, sedangkan pada 21 HST didapatkan hasil tertinggi pada perlakuan S2 ( pemberian Pseudomonas flourescens dan inkubasi $18 \mathrm{jam}$ ) yaitu $22,48 \mathrm{~cm}^{2}$, dan luas tanaman terendah pada perlakuan S1 (pemberian Pseudomonas flourescens dan tanpa inkubasi) yaitu $21,41 \mathrm{~cm}^{2}$ (Tabel 2).

Tabel 2.

Nilai rata rata perlakuan waktu inkubasi biji kedelai terhadap pertumbuhan luas daun tanaman kedelai pada $\quad 14$ dan 21 HST

\begin{tabular}{lll}
\hline Lama inkubasi & 14 HST & 21 HST \\
\hline S1 & $19,50 \mathrm{a}$ & $21,41 \mathrm{a}$ \\
S2 & $20,58 \mathrm{~b}$ & $22,48 \mathrm{~b}$ \\
S3 & $20,08 \mathrm{ab}$ & $22,28 \mathrm{ab}$ \\
S4 & $20,08 \mathrm{ab}$ & $22,17 \mathrm{ab}$ \\
S5 & $20,41 \mathrm{~b}$ & $22,36 \mathrm{ab}$ \\
\hline
\end{tabular}

Keterangan : Angka-angka yang diikuti oleh huruf yang sama tidak berbeda nyata pada uji Duncan taraf 5\%.

Pengukuran pertumbuhan luas daun pada 29 HST dilakukan dengan cara mengalikan rata rata luas daun dengan rata rata jumlah daun kedelai dengan hasil tertinggi pada perlakuan S2 ( pemberian Pseudomonas flourescens dan inkubasi 18 jam ) yaitu $122,17 \mathrm{~cm}^{2}$, dan luas tanaman terendah pada perlakuan S1 (pemberian Pseudomonas flourescens dan tanpa inkubasi) yaitu $117,47 \mathrm{~cm}^{2}$ (Tabel 3).

Tabel 3.

Nilai rata rata perlakuan waktu inkubasi biji kedelai terhadap pertumbuhan luas daun tanaman kedelai pada 28 HST

\begin{tabular}{cc}
\hline Lama inkubasi & 28 HST \\
\hline S1 & $117,47 \mathrm{a}$ \\
S2 & $122,17 \mathrm{a}$ \\
S3 & $118,82 \mathrm{a}$ \\
S4 & $119.91 \mathrm{a}$ \\
S5 & $119 \mathrm{a}$
\end{tabular}

Keterangan : Angka-angka yang diikuti oleh huruf yang sama tidak berbeda nyata pada uji Duncan taraf 5\%.

Hasil analisis statistik menunjukkan tidak berbeda nyata pada perlakuan inkubasi Pseudomonas flourescens terhadap jumlah daun pada tanaman kedelai. Hasil tertinggi pada lama inkubasi ditunjukan pada perlakuan S2 (pemberian Pseudomonas flourescens dan inkubasi $18 \mathrm{jam}$ ) dan S3 (pemberian Pseudomonas flourescens dan inkubasi $12 \mathrm{jam}$ ). Perlakuan tersebut memiliki jumlah dau rata-rata dengan nilai sama yaitu 4,83 dan hasil paling rendah ditunjukan pada S1 (pemberian Pseudomonas flourescens dan tanpa inkubasi), S4 (pemberian Pseudomonas flourescens dan inkubasi 6 jam) dan S5 (tanpa perlakuan Pseudomonas flourescens dan tanpa inkubasi). Perlakuan tersebut memiliki nilai rata-rata yang sama yaitu 4,77 (Tabel 4).

Tabel 4.

Hasil analisis jumlah daun tanaman kedelai

\begin{tabular}{cc}
\hline Lama inkubasi & 28 HST \\
\hline S1 & $4,77 \mathrm{a}$ \\
S2 & $4,83 \mathrm{a}$ \\
S3 & $4,83 \mathrm{a}$ \\
S4 & $4,77 \mathrm{a}$ \\
S5 & $4,77 \mathrm{a}$ \\
\hline
\end{tabular}

Keterangan : Angka-angka yang diikuti oleh huruf yang sama tidak berbeda nyata pada uji Duncan taraf 5\%.

Setiap perlakuan menunjukkan tidak berbeda nyata pada perlakuan inkubasi Pseudomonas flourescens terhadap jumlah berat segar tanaman kedelai. Hasil analisis total berat segar tanaman setiap perlakuan menunjukkan pada perlakuan S3 (pemberian Pseudomonas flourescens dan inkubasi $12 \mathrm{jam}$ ) yaitu 69,10 gram dan hasil paling rendah pada perlakuan S4 (pemberian Pseudomonas flourescens dan inkubasi 6 jam) yaitu 62,66 gram (Tabel 5).

Tabel 5.

Hasil analisis berat segar tanaman kedelai (gram)

\begin{tabular}{cc}
\hline Lama inkubasi & 28 HST \\
\hline S1 & $26,66 \mathrm{a}$ \\
S2 & $25,00 \mathrm{a}$ \\
S3 & $29,33 \mathrm{a}$ \\
S4 & $27,33 \mathrm{a}$ \\
S5 & $29,00 \mathrm{a}$
\end{tabular}

Keterangan : Angka-angka yang diikuti oleh huruf yang sama tidak berbeda nyata pada uji Duncan taraf $5 \%$.

Hasil analisis statistik menunjukkan tidak berbeda nyata pada perlakuan inkubasi Pseudomonas flourescens terhadap jumlah berat kering tanaman kedelai. Hasil analisis total berat kering tanaman setiap perlakuan menunjukkan perlakuan S3 (pemberian Pseudomonas flourescens dan inkubasi 12 jam) dengan nilai tertinggi 29,33 gram dan hasil paling rendah ditunjukan pada perlakuan S2 (pemberian Pseudomonas flourescens dan inkubasi 18 jam ) yaitu 25 gram. 
Website : http://agritek.unmermadiun.ac.id/index.php/agritek

\section{B. Pembahasan}

Pengaruh inkubasi Pseudomonas flourescens terhadap pertumbuhan tinggi dan luas daun tanaman kedelai menunjukkan tidak berbeda nyata terhadap parameter pertumbuhan 14 HST , 21 HST dan 28 HST. Perbandingan tanaman dengan inkubasi Pseudomonas flourescen perlakuan S2,S3 dan S4 tidak berbeda nyata dengan perlakuan S1 (pemberian Pseudomonas flourescen dan tanpa inkubasi ) dan S5 (tanpa perlakuan Pseudomonas flourescen dan tanpa inkubasi ). Hal tersebut menyatakan bahwa perlakuan pemberian bakteri tidak hanya cukup pada perlakuan pendahuluan benih akan tetapi penggunaan Pseudomonas flourescens hendaknya juga dilakukan pada fase pembibitan, berbunga, dan berbuah guna menghasilkan mutu benih yang lebih baik. Penyemprotan pada beberapa fase tersebut dilakukan untuk meningkatkan jumlah populasi bakteri sehingga dapat dimanfaatkan secara optimal sebagai agens hayati tanaman agar tetap efektif (Krishnamurthy \& Gnanamanickam, 1998).

Selain itu hasil interaksi biji kedelai yang telah diinkubasi dengan Pseudomonas flourescen terhadap berat basah dan berat kering tanaman kedelai tidak berbeda nyata. Hal tersebut diduga Pseudomonas flourescens dalam tanah tidak berkembang dengan baik hal tersebut dibuktikan dengan hasil pengukuran berat basah dan berat kering tanaman kedelai pada perlakuan S2,S3,S4 (pemberian Pseudomonas flourescens dengan inkubasi pada benih) dengan tanaman S1 (pemberian Pseudomonas flourescens dan tanpa inkubasi ) dan S5 (tanpa Pseudomonas dan tanpa inkubasi) tidak berbeda nyata. Hal tersebut diduga karena Pseudomonas flourescens sebagai mikroorganisme yang hidup dan berkembang di dalam tanah memerlukan kondisi yang sesuai yaitu sifat-sifat fisik, biologi dan kimia tanah yang berpengaruh terhadap perkembangan dan penyebaran pathogen hal tersebut antara lain adalah pH tanah, tekstur tanah, kadar hara tanah dan kadar bahan organik (Soesanto et al., 2010). Oleh karena itu informasi-informasi tentang sifat-sifat tanah yang mempengaruhi perkembangan patogen tanah akan sangat bermanfaat untuk menentukan strategi penggunaan agen hayati untuk perlakuan benih.

\section{IV.KESIMPULAN}

Penggunaan bakteri Pseudomonas flourescens pada fase perlakuan benih kedelai tidak berpengaruh nyata pada pertumbuhan tanaman kedelai. Selain itu pengaruh inkubasi Pseudomonas flourescens pada perlakuan benih kedelai juga tidak berpengaruh nyata terhadap pertumbuhan tanaman kedelai.

\section{UCAPAN TERIMAKASIH}

Ucapan terima kasih disampaikan kepada UPT Proteksi Tanaman dan Holtikultura di Pilangkenceng Kabupaten Madiun dan Balitkabi Malang yang telh mengijinkan varietas Anjasmoro untuk penelitian ini.

\section{DAFTAR PUSTAKA}

Diniyah, S. (2010). Potensi isolat bakteri Endofit sebagai penghambat pertumbuhan bakteri (Ralstonia solanacearum) dan jamur (Fusarium sp. dan Phytopthora infestans) penyebab penyakit layu pada tanaman. Skripsi Fak. Sains dan Teknologi UIN Maulana Ibrahim Malang.

Yanti, Y. \& Resti, Z. (2010). Induksi ketahanan tanaman bawang merah dengan bakteri rhizoplan indigenus terhadap penyakit hawar daun bakteri (Xanthomonas axonopodis pv allii). Dalam Loekas Soesanto, Endang Mugiastuti, Ruth Feti Rahayuniati dan Abdul Manan (Ed.). Prosiding seminar nasional pengelolaan opt ramah lingkungan Purwokerto, 10-11 November 2010.

Krishnamurthy, K. \& Gnanamanickam, S.S. (1998). Biological control of rice blast by Pseudomonas fluorescens strain pf 7-14: evaluation of a marker gene and formulations. Biol. Control 13:158-165.

Nawangsih, AA, Widjayanti, T. \& Y.Anisa, Y. (2014). Kelimpahan bakteri rizosfer pada sistem PHT biointensif serta kemampuan antagonismenya terhadap Sclerotium rolfsii pada kedelai. J. HPT Tropika 14(2): 110-120.

Soesanto, L., Mugiastuti, E. \& Rahayuniati, R.F. (2010). Kajian mekanisme antagonis Pseudomonas fluorescens P60 terhadap Fusarium oxysporum sp Lycopersici pada tanaman tomat in Vivo. J. HPT Tropika 10 (2): 108 - 115. 